\title{
OPTIMASI PENAMBAHAN KITOSAN DAN LAMA PERENDAMAN TERHADAP FISIKOKIMIA CABAI KERITING (Capsicum Annuum L.) MENGGUNAKAN RSM
}

\section{Optimization of Chitosan Addition and Soaking Time to the Physics of Curly Chili (capsicum annuum L.) Using RSM}

\author{
Benediktus Hendra Perkasa ${ }^{1,2 *}$, Joni Kusnadi ${ }^{1}$, Erni Sofia Murtini ${ }^{1}$ \\ 1) Jurusan Teknologi Hasil Pertanian, FTP Universitas Brawijaya Malang \\ Jl. Veteran, Malang 65145 \\ 2) PDD Politeknik Negeri Pontianak, Kabupaten Kapuas Hulu \\ ${ }^{*}$ Penulis Korespondensi, Email: benhendra21@gmail.com
}

\begin{abstract}
ABSTRAK
Cabai adalah produk hortikultura yang cepat rusak. Produk tersebut dapat rusak akibat dari pengaruh fisik, kimiawi, mikrobiologi, dan fisiologis. Kerusakan tidak bisa dihentikan namun dapat dikurangi dengan cara pemberian kitosan sebagai pengawet. Kitosan merupakan pengawet alami yang tidak beracun dan berfungsi sebagai pelapis produk yang aman untuk kesehatan. Dalam penelitian berikut, optimasi konsentrasi kitosan, lama waktu perendaman kitosan dan lama waktu penyimpanan cabai merah keriting pada suhu ruang untuk menghasilkan warna, tekstur dan susut bobot dianalisis menggunakan metode RSM dan perangkat lunak Design Expert D.X 7.5.1 trial (Stat-Ease Inc., Minneapolis, MN, USA) serta analisis ANOVA dan uji lanjut Fisher dengan tingkat kepercayaan 95\% menggunakan software MINITAB. Konsentrasi optimasi perlakuan terbaik yaitu konsentrasi kitosan $2.22 \%$, lama perendaman 10.52 menit dan lama penyimpanan 13.65 hari menghasilkan susut bobot $5.80 \%$, warna $a+34.20$ dan tekstur $17.06 \mathrm{~N}$.
\end{abstract}

Kata kunci: Cabai Merah Keriting, Optimasi, Kitosan, RSM

\section{ABSTRACT}

Chili is one of the horticultural products that are perishable. The damage occurs due to physical, chemical, microbiological, and physiological influences. This condition cannot be stopped but it can be reduced by giving chitosan as a preservative. Chitosan is a natural preservative that functions as a coating product that is non-toxic and safe for health. In this study, the optimization of chitosan concentration, chitosan immersion time, and storage time of curly red chili at room temperature to produce color, texture, and storage time were analyzed using the RSM method and Design Expert DX 7.5.1 trial software (Stat-Ease Inc., Minneapolis, MN, USA) and ANOVA analysis and Fisher's follow-up test with a 95\% confidence level using MINITAB software. The best treatment optimization concentration is chitosan concentration 2.22\%, soaking time 10.52 minutes, and storage time 13.65 days resulting in a weight loss of $5.80 \%$, color a +34.20 , and texture $17.06 \mathrm{~N}$.

Keywords: Curly Red Chili, Optimization, Chitosan, RSM

\section{PENDAHULUAN}

Cabai merah keriting adalah salah satu jenis sayuran yang cepat rusak sehingga jangka waktu penyimpanannya tidak lama. Apabila proses distribusi cabai melambat, maka cabai akan mengalami kerusakan dari segi kualitas dan kuantitasnya. Kerusakan bisa terjadi disebabkan oleh pengaruh mikrobiologi, fisiologis fisik, dan kimiawi. Menurut Syahri et al. 
(2018), kerusakan fisik dan fisisologis pada cabai dapat terjadi saat proses pengangkutan dan penyimpanan. Proses metabolisme cabai merah setelah panen pun tetap berjalan, contohnya yaitu laju respirasi. Cabai merah keriting yang memiliki kematangannya $60 \%$ memiliki umur simpan 5 hari pada suhu $28^{\circ} \mathrm{C}-32^{\circ} \mathrm{C}$ dan jika disimpan pada suhu kurang dari $10^{\circ} \mathrm{C}\left(45^{\circ} \mathrm{F}\right)$ dapat bertahan selama 10 hari (Susanto, 2006).

Kerusakan pada cabai merah keriting tidak bisa dihentikan namun dapat dikurangi dengan salah satu cara yaitu pelapisan menggunakan kitosan. Kitosan dapat melapisi suatu produk pangan dan menjadi pengawet alami karena tidak mengandung toksin sehingga tidak berbahaya bagi kesehatan (Kays, 1991). Limbah pada pengolahan industri perikanan khususnya udang, menghasilkan produk turunan polimer kitin yaitu kitosan. Kitosan memiliki kemampuan sebagai pelapisan (coating) untuk meningkatkan daya simpan, menurunkan laju respirasi, menghambat tumbuhnya kapang dan patogen psikotrofik, dan mengurangi pembentukan etilen, karbondioksida, serta dapat membentuk film yang sesuai dan memiliki sifat biodegradable serta biokompatibel sehingga kerusakan dan pematangan buah maupun sayuran dapat terhambat (Jianglian D. dan Shaoying Z, 2013). Jiang dan Tsang G (2005), menyatakan bahwa pada penyimpanan buah leci, kandungan antosianin yang menurun dan aktivitas polyphenol oxidase yang meningkat dapat dihambat dengan mengaplikasikan coating kitosan (2\% kitosan dalam 5\% asam asetat). Menurut Ghaouth et al. (1892) dan Melly et al. (2012), Laju respirasi dan produksi etilen di buah tomat dapat diturunkan dengan pelapisan menggunakan kitosan ( $1 \%$ dan $2 \%$ dalam $0.25 \mathrm{~N} \mathrm{HCl})$.

Peneliti sebelumnya menjelaskan bahwa lapisan kitosan mengurangi susut buah, laju respirasi, kehilangan warna, dan memberi pengaruh dalam pengendalian kerusakan buah yang disebabkan spesies Penicillum (Chien et al., 2007). Dalam penelitian Yage et al. (2010), menyatakan bahwa pemberian konsentrasi kitosan 4\% yang disimpan pada suhu $8^{\circ} \mathrm{C}$ selama 35 hari sifat fisik dipertahankan dengan baik tidak mengalami susut buah dan kerutan terhadap buah paprika. Selanjutnya peneliti sebelumnya Prabha et al., (2015) menyatakan pemberian kitosan 3\% perubahan dimulai pada hari ke tujuh. Selanjutnya peneliti Raymond et al., (2012) menyatakan bahwa kitosan $0.5 \%, 1 \%$ dan $2 \%$, mikrobiologis jumlah sel yang hidup total menurun dengan meningkat nya konsentrasi.

Penelitian ini diharapkan dapat menghasilkan sifat fisik cabai keriting yang susut bobot rendah, warna cerah dan bertekstur keras dalam waktu simpan yang lama. Dalam penelitian ini konsentrasi kitosan, lama perendaman dengan kitosan dan lama penyimpanan dianalisis menggunakan metode Response Surface Methodology (RSM).

\section{BAHAN DAN METODE}

Penelitian dilaksanakan pada bulan Mei hingga bulan Desember 2019 bertempat di Laboratorium Kimia dan Biokimia Pangan, Laboratorium Mikrobiologi Pangan, Laboratorium Bioteknologi Pangan dan Laboratorium Pengolahan dan Rekayasa Pangan Jurusan Teknologi Hasil Pertanian Universitas Brawijaya Malang.

Sampel penelitian berupa cabai merah keriting (varietas Laba F1) dengan tingkat kematangan 75 hari setelah tanam yang didapatkan dari petani di Desa Tirtomarto, Kec. Ampelgading, Kab. Malang. Serbuk kitosan yang terbuat dari cangkang udang (CHITOUCH), untuk kemasan yang digunakan: Polyethylene (TIC-TAS).

\section{Bahan}

Bahan yang digunakan untuk proses analisis komponen kimia cabai merah keriting segar diantaranya standar capsaicin, acetonitril HPLC grade, aquabides HPLC grade, aquabides, etanol 96\% (Smartlab), standar asam galat, Folin Ciocalteu (Merck), $\mathrm{Na}_{2} \mathrm{CO}_{3}$, standar quercetin (Sigma), $\mathrm{NaNO}_{3}, \mathrm{AlCl}_{3}, \mathrm{NaOH}, \mathrm{DPPH}$, asam tatanat (Sigma), standar asam askorbat, $\mathrm{KH}_{2} \mathrm{PO}_{4}, \mathrm{Na}_{2} \mathrm{HPO}_{4} 2 \mathrm{H}_{2} \mathrm{O}$, natrium oksalat, aquades, kertas saring halus dan seluruh bahan kimia berstatus pro analisis. 
Alat

Alat-alat yang digunakan dalam penelitian ini yaitu neraca analitik (Mattler AE 160), testing machine dan color reader.

\section{Desain Penelitian}

Optimasi pengawetan cabai merah keriting pemberian lapisan kitosan pada bahan menggunakan metode permukaan respon (RSM). Penelitian ini menggunakan variabel antara lain yaitu konsentrasi kitosan, lama perendaman kitosan dan lama penyimpanan.

Tabel 1. Desain Percobaan Untuk Membangun Model Fungsi Respon Rancangan CCD

\begin{tabular}{ccccccc}
\hline STD & \multicolumn{3}{c}{ Variabel Bebas } \\
\cline { 2 - 6 } & $\begin{array}{c}\text { Kosentrasi } \\
\text { Kitosan } \\
(\%)\end{array}$ & $\begin{array}{c}\text { Lama } \\
\text { Perendaman } \\
\text { (menit) }\end{array}$ & $\begin{array}{c}\text { Hari } \\
\text { Penyimpanan } \\
\text { (Hari Ke) }\end{array}$ & $\begin{array}{c}\text { Susut } \\
\text { Bobot } \\
(\%)\end{array}$ & $\begin{array}{c}\text { Warna } \\
(\mathbf{a +})\end{array}$ & $\begin{array}{c}\text { Tekstur } \\
(\mathbf{N})\end{array}$ \\
\hline 1 & 1.00 & 5.00 & 15.00 & & & \\
2 & 3.00 & 5.00 & 15.00 & & & \\
3 & 1.00 & 15.00 & 15.00 & & \\
4 & 3.00 & 15.00 & 15.00 & & \\
5 & 1.93 & 10.00 & 10.00 & & \\
6 & 3.07 & 10.00 & 10.00 & & \\
7 & 1.00 & 10.76 & 20.00 & & \\
8 & 3.00 & 10.24 & 20.00 & & \\
9 & 2.00 & 5.00 & 10.00 & & \\
10 & 2.00 & 15.00 & 10.00 & & \\
11 & 2.00 & 5.00 & 20.00 & & \\
12 & 2.00 & 15.00 & 20.00 & & \\
13 & 2.00 & 10.00 & 15.00 & & \\
14 & 2.00 & 10.00 & 15.00 & & \\
15 & 2.00 & 10.00 & 15.00 & & \\
16 & 2.00 & 10.00 & 15.00 & & \\
17 & 2.00 & 10.00 & 15.00 & & & \\
\hline
\end{tabular}

\section{Tahapan Penelitian}

Optimasi konsentrasi kitosan, lama perendaman dan hari pengamatan menggunakan rancangan Respon Surface Methodology (RSM).

\section{Metode}

Optimasi pengawetan cabai merah keriting secara pemberian lapisan kitosan pada bahan menggunakan metode permukaan respon (RSM). Penelitian ini mengkaji beberapa variabel yaitu konsentrasi kitosan, lama perendaman kitosan, dan lama penyimpanan.

\section{Prosedur Analisis}

Optimasi menggunakan peranti lunak Desain Expert (Version 7.1, Stat-Ease Inc., Minneapolis, $M M$ ). Semua analisis dilakukan dalam tiga ulangan dan hasilnya diberikan \pm standar deviasi.

\section{HASIL DAN PEMBAHASAN}

\section{Optimasi Pemberian Kitosan}

\section{Rancangan Percobaan}

Penentuan lower limit dan upper limit berdasarkan penelitian terdahulu yang telah banyak meneliti tentang kitosan pada cabai merah keriting. Kombinasi perlakuan optimasi beserta data respon susut bobot, warna dan tekstur rancangan CCD tertera pada Tabel 2. 
Tabel 2. Data Variabel Bebas dan Respon dari Rancangan CCD.

\begin{tabular}{ccccccc}
\hline STD & \multicolumn{3}{c}{ Variabel Bebas } & \multicolumn{3}{c}{ Respon } \\
\cline { 2 - 7 } & $\begin{array}{c}\text { Konsentrasi } \\
\text { Kitosan (\%) }\end{array}$ & $\begin{array}{c}\text { Lama } \\
\text { Perendaman } \\
\text { (menit) }\end{array}$ & $\begin{array}{c}\text { Lama } \\
\text { Penyimpanan } \\
\text { (hari) }\end{array}$ & $\begin{array}{c}\text { Susut } \\
\text { Bobot } \\
(\mathbf{g})\end{array}$ & $\begin{array}{c}\text { Warna (a+) } \\
\mathbf{( N )}\end{array}$ & $\begin{array}{c}\text { Tekstur } \\
\text { (N) }\end{array}$ \\
\hline 1 & 1 & 5 & 15 & 34.1 & 12.9 & 5.2 \\
2 & 3 & 5 & 15 & 14.1 & 25.3 & 11.3 \\
3 & 1 & 15 & 15 & 30.7 & 12.9 & 7 \\
4 & 3 & 15 & 15 & 12.8 & 27.9 & 9.2 \\
5 & 1 & 10 & 10 & 28.6 & 20.5 & 10.5 \\
6 & 3 & 10 & 10 & 15 & 29.9 & 13.6 \\
7 & 1 & 10 & 20 & 37.2 & 10.4 & 4.7 \\
8 & 3 & 10 & 20 & 16.3 & 25.4 & 6.3 \\
9 & 2 & 5 & 10 & 16.6 & 26.2 & 11.2 \\
10 & 2 & 15 & 10 & 14.8 & 27.2 & 14.1 \\
11 & 2 & 5 & 20 & 19.7 & 20.4 & 5.0 \\
12 & 2 & 15 & 20 & 18.2 & 22.2 & 4.1 \\
13 & 2 & 10 & 15 & 7.3 & 33.6 & 16.9 \\
14 & 2 & 10 & 15 & 8.6 & 32.1 & 16.8 \\
15 & 2 & 10 & 15 & 7.4 & 33.5 & 16.2 \\
16 & 2 & 10 & 15 & 7.6 & 33.3 & 16.4 \\
17 & 2 & 10 & 15 & 8.4 & 33.4 & 15.9 \\
\hline
\end{tabular}

Sumber: software Design Expert versi 7.1.

\section{Pemodelan dan Analisis Respon Respon Susut Bobot}

Pemilihan model berdasarkan ringkasan model statistic (Model Summary Statistik) RSM menyarankan kuadratik dimana, standar devisi yaitu 0,83 lebih kecil dari model lainnya. Model kuadratik memiliki nilai Adjusted $\mathrm{R}^{2}$ 0,99 dan predicted $\mathrm{R}^{2}$ sebesar 0,96. Data ini menunjukkan variabel konsentrasi kitosan, lama perendaman kitosan dan lama penyimpanan meberikan berpengaruh terhadap respon bobot buah sebesar $99 \%$ dan sisa $1 \%$ disebabkan oleh faktor lain yang tidak digunakan sebagai variabel yang diteliti. Hasil dapat dilihat pada Tabel 3.

Tabel 3. Hasil Pemilihan Model Berdasarkan Ringkasan Model Statistik Respon Susut Bobot

\begin{tabular}{lcccccc}
\hline \multicolumn{1}{c}{ Source } & Std. & $\begin{array}{c}\boldsymbol{R} \text { - } \\
\text { Dev }\end{array}$ & $\begin{array}{c}\text { Adjuared } \\
\text { R-Squaared }\end{array}$ & $\begin{array}{c}\text { Predicted } \\
\text { E-Squared }\end{array}$ & PRESS & \\
\hline Linear & 7.75 & 0.4714 & 0.3494 & 0.1955 & 1189.36 & \\
2FI & 8.76 & 0.4811 & 0.1698 & 0.4102 & 2084.81 & \\
Quadratik & $\underline{0.83}$ & $\underline{0.9967}$ & $\underline{0.9926}$ & $\underline{0.9643}$ & $\underline{52.76}$ & $\underline{\text { Suqqested }}$ \\
Cubit & $\mathbf{0 . 6 5}$ & 0.9989 & $\underline{\mathbf{0 . 9 9 5 5}}$ & & & \\
\hline
\end{tabular}

Chen et al. (2009) menyatakan bahwa regresi model yang memiliki nilai $R^{2}>0.9000$ berarti memiliki korelasi yang tinggi. Pemilihan model juga difokuskan pada nilai PRESS yang paling tinggi yaitu 52.76, sehingga model ini kuadratik disarankan (suggested) pada analisis ringkasan model. Analisis ragam pada model dapat memberi penjelasan tentang korelasi antara variabel bebas dan respon. Hasil ANOVA dari respon susut bobot dengan model kuadratik tertera pada Tabel 4. 
Optimasi Penambahan Kitosan dan Lama Perendaman - Perkasa, dkk Jurnal Pangan dan Agroindustri Vol. 9 No.1: 13-24, Jan 2021

Tabel 4. Hasil Analisis Ragam (ANOVA) pada Respon Susut Bobot Model Kuadratik

\begin{tabular}{lcccccc}
\hline \multicolumn{1}{c}{ Source } & $\begin{array}{c}\text { Sum of } \\
\text { Squares }\end{array}$ & Df & $\begin{array}{c}\text { Mean } \\
\text { Square }\end{array}$ & $\begin{array}{c}\text { F- } \\
\text { value }\end{array}$ & $\begin{array}{c}\text { p-value Prob }> \\
\text { F }\end{array}$ & Ket \\
\hline Model & 1473.53 & 9 & 163.73 & 238.02 & $<0.0001$ & Signifikan \\
A-Konsentrasi & 655.22 & 1 & 655.22 & 953.22 & $<0.0001$ & \\
kitosan & 8.00 & 1 & 8.00 & 11.63 & 0.0113 & \\
B-lama Perendaman & 33.62 & 1 & 33.62 & 48.88 & 0.0002 & \\
C-Lama & 1.10 & 1 & 1.10 & 1.60 & 0.2460 & \\
penyimpanan & 13.32 & 1 & 13.32 & 19.37 & 0.0032 & \\
AB & 0.022 & 1 & 0.022 & 0.033 & 0.8616 & \\
AC & 508.32 & 1 & 508.32 & 738.99 & $<0.0001$ & \\
BC & 68.64 & 1 & 68.64 & 99.78 & $<0.0001$ & \\
$A^{2}$ & 122.21 & 1 & 122.21 & 177.67 & $<0.0001$ & \\
$B^{2}$ & 4.81 & 7 & 0.69 & & & Sot \\
$\mathrm{C}^{2}$ & 3.13 & 3 & 1.04 & 2.49 & 0.1997 & signifikan \\
Residual & 1.68 & 4 & 0.42 & & & \\
Lack of Fit & 1478.35 & 16 & & & & \\
Pure Error & Cor Total & &
\end{tabular}

Ket: $A B, A C, B C, A^{2}, B^{2}$, dan $C^{2}=$ interaksi antar perlakuan

$A=$ variabel $X^{1}$ (konsentrasi kitosan), $B=$ Variabel $X_{2}$ (lama perendaman) dan $C=$ varaibel $X_{3}$ (Lama Penyimpanan).

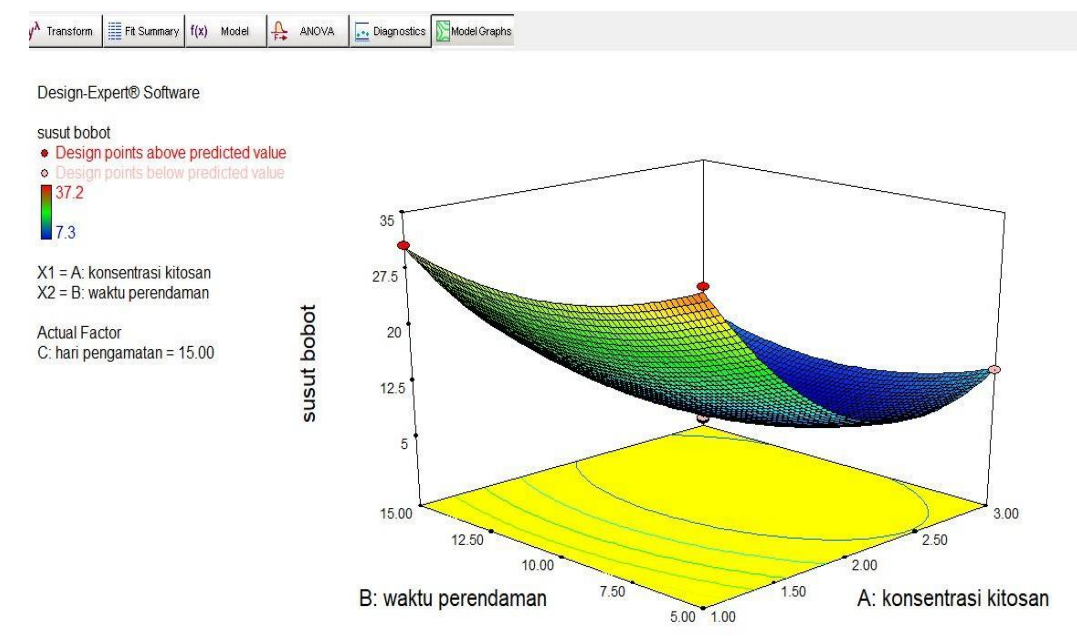

Gambar 1. Kontur 3D Permukaan Respon Susut Bobot

Kualitas buah setelah panen dapat dilihat dengan penggunaan parameter susut bobot. Hal tersebut dikarenakan setelah proses panen, aktivitas fisiologi pada buah antara lain respirasi dan transpirasi masih berjalan. Susanto (2006), menyatakan bahwa proses fisiologis yang masih terjadi pada produk setelah dipanen atau dipetik dari tanaman berhubungan erat dengan berkurangnya volume atau berat produk tersebut. Pengaruh variabel bebas terhadap respon dapat digambarkan menggunakan counter 3D respon.

Hasil analisis ANOVA menunjukkan bahwa pemberian lapisan kitosan secara signifikan mengurangi susut bobot dari cabai merah keriting selama 20 hari penyimpanan pada suhu ruang. Hal ini diduga karena lapisan kitosan yang melapisi permukaan buah sehingga mampu menghambat proses respirasi pada lentisel di kulit buah. Hal ini sesuai dalam penelitian (Trotel-Aziz et al., 2014), menyatakan bahwa penerapan lapisan kitosan menunda perubahan kualitas internal, mengurangi penurunan berat buah, mengurangi kehilangan air dari buah selama penyimpanan dan membantu menjaga kualitas buah. Peneliti terdahulu menyatakan menyatakan bahwa buah lada yang diberi lapisan kitosan $2 \%$ penurunan berat buah dikendalikan secara efektif (Fard et al., 2010). Selanjutnya 
ditambahkan oleh Chien et al. (2007), menyatakan konsentrasi kitosan $2 \%$ kehilangan berat buah tertinggi $19.68 \%$ dan terendah $10.27 \%$.

Secara umum kitosan dapat membantu mengurangi kehilangan kelembaban dan mempercepat respirasi dengan mengurangi penyerapan oksigen buah dari lingkungan karena kitosan merupakan biopolimer serbaguna yang bermanfaat karena pembentukan filmnya, sifat biokimia, aktivitas mikroba dan elisitasi respon pertahanan dalam jaringan tanaman (Badawy et al, 2009).

\section{Pemodelan dan Analisis Respon Respon Warna a+}

Penentuan model berdasarkan pengujian ketidaksesuaian model (lack of fit tests) program menyarankan kuadratik dengan nilai $p$ value $0.2026(20.26 \%)$ lebih besar dari $5 \%$. Pada model kubik, program tidak menampilkan nilai $\mathrm{p}$ dan model ini dinyatakan aliased atau tidak disarankan oleh program sehingga model ini tidak digunakan.

Tabel 5. Hasil Pemilihan Model Berdasarkan Ringkasan Model Statistik Respon Warna a+

\begin{tabular}{|c|c|c|c|c|c|c|}
\hline Source & $\begin{array}{l}\text { Std. } \\
\text { Dev }\end{array}$ & $\begin{array}{c}R- \\
\text { Squared }\end{array}$ & $\begin{array}{c}\text { Adjusted } \\
\text { R-Squaared }\end{array}$ & $\begin{array}{l}\text { Predicted } \\
\text { E-Squared }\end{array}$ & PRESS & \\
\hline Linear & 6.25 & 0.4528 & 0.3265 & 0.1916 & 749.31 & \\
\hline $2 \mathrm{FI}$ & 7.05 & 0.4633 & 0.1412 & 0.3569 & 1257.61 & \\
\hline Quadratik & 0.80 & 0.9951 & 0.9888 & 0.9467 & 49.45 & Suqqested \\
\hline Cubit & 0.63 & 0.9983 & 0.9931 & & & Aliased \\
\hline
\end{tabular}

Penentuan model berdasarkan ringkasan model statistik. Model kuadratik Tabel diatas menjelaskan bahwa model kuadratik memiliki nilai $\mathrm{R}^{2}$, adjusted $\mathrm{R}^{2}$ dan predicted $\mathrm{R}^{2}$ lebih besar daripada model Linear dan 2FI. Standar deviasi pada model kuadratik 0,80 lebih kecil dibandingkan model linear (6.25) dan 2FI (7.05). Standar deviasi model kuadratik lebih kecil dibandingkan model linear dan $2 \mathrm{FI}$. Model kuadratik mempunyai nilai Adjusted $\mathrm{R}^{2}$ maksimal sebesar 0.98 dan predicted $R^{2}$ sebesar 0.94. Data ini menunjukkan variabel konsentrasi kitosan, lama perendaman kitisan dan lama penyimpanan berpengaruh terhadap respon warna a+ sebesar $99 \%$ dan sisa $1 \%$ disebabkan karena faktor lain yang bukan dijadikan variabel yang teliti. (Chen et al., 2009) menyatakan bahwa regresi model yang memiliki nilai $R^{2}>0.9000$ berarti memiliki korelasi yang tinggi. Pemilihan model juga difokuskan pada nilai PRESS yang paling tinggi yaitu 49.45, sehingga model ini kuadratik disarankan (suggested) pada analisis ringkasan model. Analisis ragam pada model dapat menunjukkan korelasi variabel bebas dengan respon. Hasil ANOVA dari respon warna dengan model kuadratik tertera pada Tabel 6.

Tabel 6. Hasil ANOVA Respon Warna $\mathrm{a}^{+}$

\begin{tabular}{lcccccc}
\hline \multicolumn{1}{c}{ Source } & $\begin{array}{c}\text { Sum of } \\
\text { Squares }\end{array}$ & Df & $\begin{array}{c}\text { Mean } \\
\text { Square }\end{array}$ & $\begin{array}{c}\text { F- } \\
\text { value }\end{array}$ & $\begin{array}{c}\text { p-value Prob } \\
>\text { F }\end{array}$ & Ket \\
\hline Model & 922.33 & 9 & 102.48 & 158.46 & 0.0001 & Signifikan \\
$\begin{array}{l}\text { A-Konsentrasi } \\
\text { kitosan }\end{array}$ & 335.41 & 1 & 335.41 & 516.63 & 0.0001 & \\
B-lama & & & & & & \\
Perendaman & 3.64 & 1 & 3.64 & 5.64 & 0.0493 & \\
C-Lama & & & & & & \\
penyimpanan & 80.64 & 1 & 80.64 & 124.70 & 0.0001 & \\
AB & 1.69 & 1 & 1.69 & 2.61 & 0.1500 & \\
AC & 7.84 & 1 & 7.84 & 12.12 & 0.0102 & \\
BC & 0.16 & 1 & 0.16 & 0.25 & 0.6341 & \\
A $^{2}$ & 264.11 & 1 & 264.11 & 408.39 & 0.0001 & \\
B $^{2}$ & 125.98 & 1 & 125.98 & 194.80 & 0.0001 & \\
C $^{2}$ & 56.71 & 1 & 56.71 & 87.69 & 0.0001 & \\
Residual & 4.53 & 7 & 0.65 & & & \\
\hline
\end{tabular}


Optimasi Penambahan Kitosan dan Lama Perendaman - Perkasa, dkk Jurnal Pangan dan Agroindustri Vol. 9 No.1: 13-24, Jan 2021

\begin{tabular}{lcccccc}
\hline Lack of Fit & 2.94 & 3 & 0.98 & 2.46 & 0.2025 & $\begin{array}{c}\text { Not } \\
\text { signifikan }\end{array}$ \\
Pure Error & 1.59 & 4 & 00.40 & & & \\
Cor Total & 926.96 & 16 & & & & \\
\hline
\end{tabular}

Ket: $\mathrm{AB}, \mathrm{AC}, \mathrm{BC}, \mathrm{A}^{2}, \mathrm{~B}^{2}$, dan $\mathrm{C}^{2}=$ interaksi antar perlakuan

$A=$ variabel $X^{1}$ (konsentrasi kitosan), $B=$ Variabel $X_{2}$ (lama perendaman) dan $C=$ varaibel $X_{3}$ (Lama Penyimpanan).

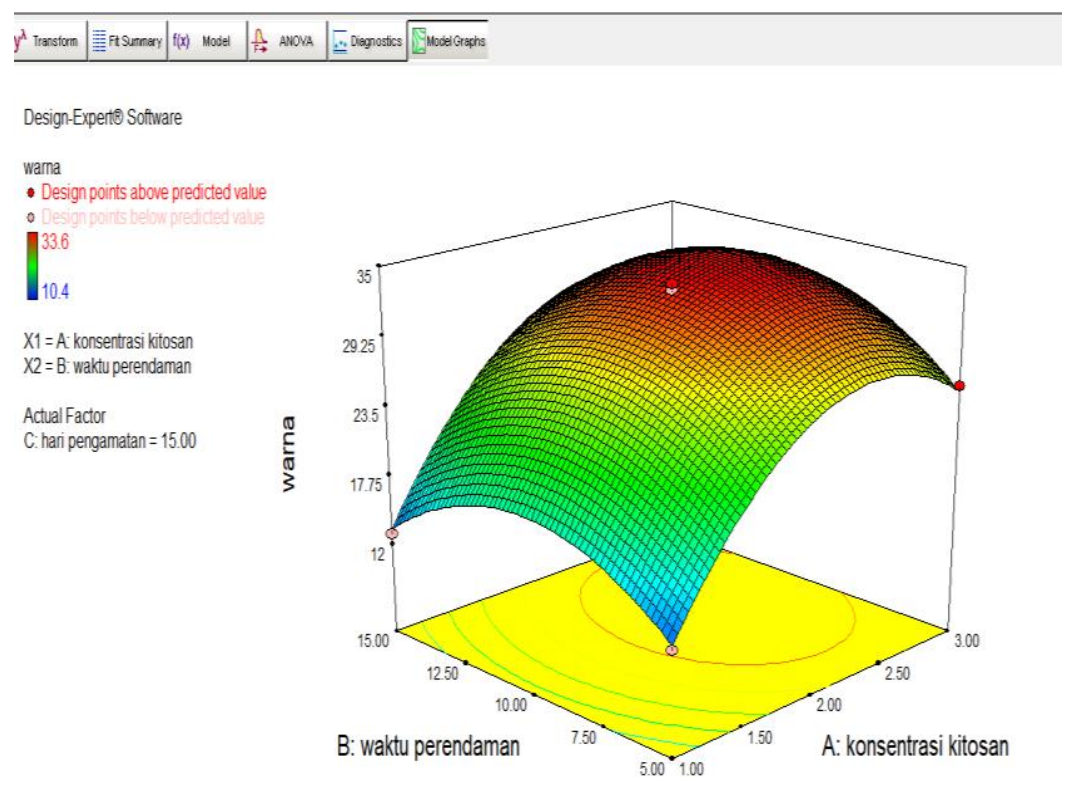

Gambar 2. Kontur 3D Permukaan Respon Warna a+

Nilai a+ ialah nilai warna kemerahan. Apabila kematangan buah meningkat maka nilai warna a+ akan semakin bertambah pula. Semakin tinggi konsentrasi kitosan dan lama perendaman buah dengan kitosan akan semakin lama ketahanan warna cabai selama masa simpan 15 hari nilai kemerahan lebih tinggi dibandingkan masa simpan 20 hari. Hal ini karena lapisan kitosan mampu menghambat laju respirasi yang mengakibatkan lambat nya proses sintesis pigmen pada buah. Menurut Cahyono (2008), kandungan pigmen pada buah yang mengalami proses degrasi ataupun proses sintesis menjadi faktor yang menyebabkan warna berubah. Ditambahkan oleh Susilowati (2008) bahwa cabai merah selama penuaan buah akan mempunyai warna merah yang berasal dari pigmen karotenoid. Menurut Saputro dan Susanto (2016), karotenoid akan menyebabkan suatu produk pangan memiliki warna merah. Karotenoid adalah pigmen alami yang terkandung pada tanaman. Karotenoid menjadi tidak stabil apabila terkena panas, oksidator, dan cahaya. Rangkaian ganda kerangka karotenoid pada bagian tengah bersifat sensitif dengan serangan oksidator. Stimulasi dari cahaya panas, peroksidasi, logam seperti Fe dan enzim menyebabkan terjadinya proses oksidasi pada karotenoid. Secara umum konsentrasi karotenoid, flavonoid, asam askorbat, phenolic acids, dan komponen kimia lainnya akan meningkat sejalan dengan laju respirasi buah yang meningkat pula. Penelitian Ardasania (2014) menyatakan apabila cabai merah dengan aplikasi kitosan dapat mempertahankan warna hingga 12 hari penyimpanan pada suhu ruang.

\section{Pemodelan dan Analisis Respon Respon Tekstur}

Penentuan respon optimal yang didasarkan pada pemilihan model yang tepat untuk evaluasi model dari sistem komputerisasi Design Expert adalah menggunakan urutan jumlah kuadrat (Sequential Model Sum of Squares), pengujian ketidaksesuaian model (Lack of Fit tests) dan ringkasan model statistic (Model Summary Statistic). Penentuan model berdasar pada jumlah kuadrat (sequential model sum of squares) program menyarankan model 
kuadratik Model berikutnya quadratik, yang memiliki nilai p sebesar $<0.0001(0,1 \%)$ lebih kecil dari $0.05(5 \%)$ yang menampakkan bahwa kemungkinan kesalahan pada model ini kurang dari $5 \%$ atau bermakna jika model kuadratik mempunyai pengaruh yang signifikan terhadap respon bobot buah. Model kuadratik tersebut mempunyai nilai $F$ (F-test) yang tertinggi dan $\mathrm{p}$-value Prob $>\mathrm{F}$ terendah. Hal ini didukung oleh pernyataan Montgomery (2001), model yang digunakan akan semakin nyata hubungannya apabila nilai $F$ yang tinggi atau nilai $p$-value Prob $>F$ yang semakin kecil. Sedangkan model linier, mean, 2FI dan kubik mempunyai $p$ value lebih besar dari 0.005 .

Pemilihan model berdasarkan percobaan ketidaksesuaian model (lack of fit test) program menyarankan model kuadratik nilai $p$ value $0.0585(5.85 \%)$ lebih besar dari $5 \%$. Model kuadratik menunjukkan tidak berbeda signifikan pada nilai $p<5 \%$ sehingga diartikan model ini merupakan model yang tepat untuk respon tekstur Program menunjukkan model kuadratik sebagai model yang terpilih (suggested) karena memiliki nilai $\mathrm{p}$ lebih besar dari $5 \%$. Pemilihan model berdasarkan ringkasan model statistic program menyarankan model kuadratik. Standar deviasi model kuadratik lebih kecil dibandingkan model linear dan $2 \mathrm{FI}$. Model kuadratik mempunyai nilai Adjusted $\mathrm{R}^{2}$ maksimal yaitu 0.97 dan predicted $\mathrm{R}^{2}$ sebesar 0.95. Data ini menunjukkan variabel konsentrasi kitosan, lama perendaman kitisan dan lama penyimpanan berpengaruh terhadap respon tekstur sebanyak $98 \%$ sedangkan nilai sebanyak $2 \%$ dikarenakan oleh faktor penyebab lain yang bukan dijadikan variabel yang teliti. Dalam penelitian (Chen et al., 2009) menyatakan bahwa regresi model yang memiliki nilai $R^{2}>0.9000$ berarti memiliki korelasi yang tinggi. Pemilihan model juga difokuskan pada nilai PRESS yang paling tinggi yaitu 50.68 , sehingga model ini kuadratik disarankan (suggested) pada analisis ringkasan model. Analisis ragam atas model dapat menampakan korelasi antara variabel bebas dengan respon. Hasil ANOVA untuk respon bobot buah dengan model kuadratik tertera dalam Tabel 7.

Tabel 7. Hasil Analisis Ragam (ANOVA) Pada Respon Warna a+ Model Kuadratik

\begin{tabular}{lcccccc}
\hline \multicolumn{1}{c}{ Source } & $\begin{array}{c}\text { Sum of } \\
\text { Squares }\end{array}$ & Df & $\begin{array}{c}\text { Mean } \\
\text { Square }\end{array}$ & F-value & $\begin{array}{c}\text { p-value } \\
\text { Prob }>\text { F }\end{array}$ & Keterangan \\
\hline Model & 356.07 & 9 & 39.56 & 73.03 & $<0.0001$ & Signifikan \\
$\begin{array}{l}\text { A-Konsentrasi } \\
\text { kitosan }\end{array}$ & 21.13 & 1 & 21.13 & 39.00 & 0.0004 & \\
B-lama & & & & & & \\
Perendaman & 0.25 & 1 & 0.25 & 0.45 & 0.5228 & \\
C-Lama & 105.13 & 1 & 105.13 & 194.06 & $<0.0001$ & \\
penyimpanan & 3.80 & 1 & 3.80 & 7.02 & 0.0330 & \\
AB & 0.58 & 1 & 0.56 & 1.04 & 0.3421 & \\
AC & 4.20 & 1 & 4.20 & 7.76 & 0.0271 & \\
BC & 70.18 & 1 & 70.18 & 129.54 & $<0.0001$ & \\
$\mathrm{~A}^{2}$ & 73.66 & 1 & 73.66 & 135.97 & $<0.0001$ & \\
$\mathrm{~B}^{2}$ & 54.04 & 1 & 54.04 & 99.76 & $<0.0001$ & \\
$\mathrm{C}^{2}$ & 3.79 & 7 & 0.54 & & & \\
Residual & 3.10 & 3 & 1.03 & 5,97 & 0.0585 & Not signifikan \\
Lack of Fit & 0.69 & 4 & 0.17 & & & \\
Pure Error & 359.86 & 16 & & & & \\
Cor Total & &
\end{tabular}

Ket: $A B, A C, B C, A^{2}, B^{2}$, dan $C^{2}=$ interaksi antar perlakuan

$A=$ variabel $X^{1}$ (konsentrasi kitosan), $B=$ Variabel $X_{2}$ (lama perendaman) dan $C=$ Variabel $X_{3}$ (Lama Penyimpanan). 


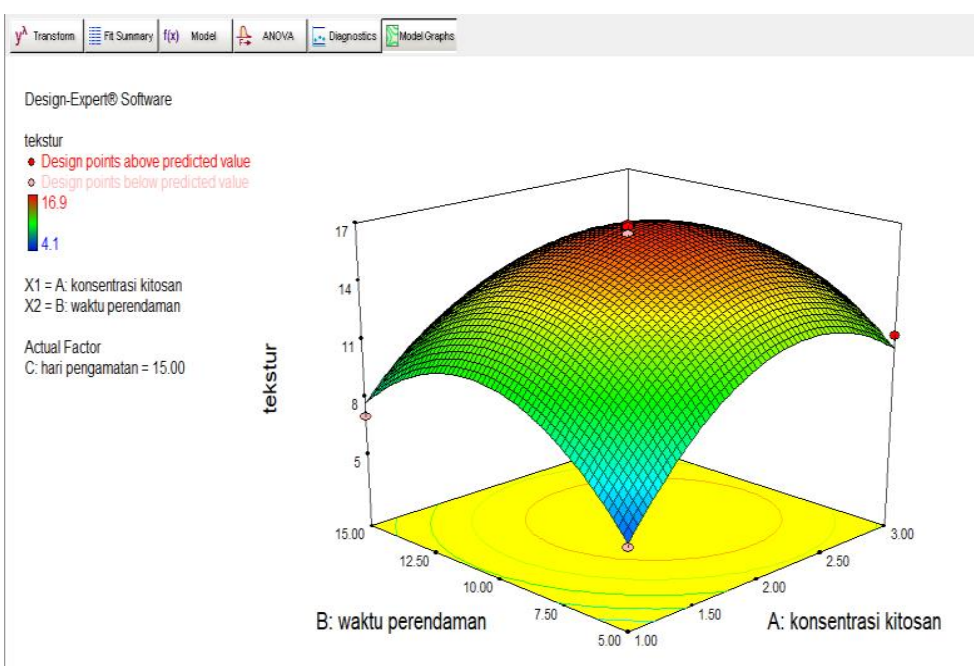

Gambar 3. Kontur 3D Permukaan Respon Tekstur

Gambar counter 3D dapat dilihat dari perubahan warna, semakin merah menyebabkan semakin tinggi nilai respon yang dihasilkan, sebaliknya semakin berwarna biru maka semakin rendah respon yang dihasilkan yang dipengaruhi oleh variabel bebas.

Konsentrasi kitosan dan lama perendaman kitosan menunjukkan hasil yang berbeda.

Semakin tinggi konsentrasi kitosan dan lama perendaman dengan kitosan dapat mempertahankan tingkat kekerasan kulit buah cabai merah keriting pada penyimpanan 15 hari pada suhu ruang. Hal ini karena pemberian kitosan dapat menghambat proses pelunakan pada permukaan kulit buah cabai yang bisa menghambat laju respirasi produk. Penghambatan respirasi ini menahan laju air dari sel cabai. Jika laju kehilangan air dapat dihambat maka pelunakan kulit buah dapat ditunda. Dalam penelitian Sitorus et al. (2014), menyatakan bahwa selama proses penyimpanan berlangsung pergantian bagian dari protopektin yang tidak dapat larut air menjadi larut air, sehingga menyebabkan menurun nya daya kerapatan dinding sel yang merekatkan sel satu dengan sel yang lainnya, sehingga kepadatan bentuk buah berubah menjadi lunak.

\section{Penentuan Titik Optimal Respon dan Verifikasi}

Tahap selanjutnya setelah melakukan analisis terhadap respon yang ditentukan akibat pengaruh konsentrasi kitosan, lama waktu perendaman dan lama waktu penyimpanan cabai merah keriting pada suhu ruang dalam metode permukaan respon adalah penentuan tiitk optimum dari variabel bebas terhadap respon bobot buah, warna a+ dan tekstur. Penentuan titik optimum dilakukan berdasarkan kriteria yang kita inginkan dengan menentukan tingkat kepentingan dan tujuan yang diharapkan dari setiap faktor dan variabel dalam penelitian tersebut. Apabila kriteria telah ditentukan, maka program Desain Expert DX 7.5.1 secara otomatis akan memberikan solusi optimal. Solusi yang terpilih tersebut akan diverifikasi dengan percobaan dari solusi yang diberikan secara aktual. Penentuan kriteria dalam penelitian ini berdasarkan optimasi pemberian kitosan pada cabai keriting merah yang ditunjukkan pada Tabel 8.

Tabel 8. Solusi Titik Optimum dan Verifikasi dari Kriteria Terpilih.

\begin{tabular}{lccccccc}
\hline & $\begin{array}{c}\text { Konsentrasi } \\
\text { Kitosan (\%) }\end{array}$ & $\begin{array}{c}\text { Lama } \\
\text { Perendaman } \\
\text { (menit) }\end{array}$ & $\begin{array}{c}\text { Lama } \\
\text { Penyimpanan } \\
\text { (hari) }\end{array}$ & $\begin{array}{c}\text { Susut } \\
\text { Bobot } \\
(\%)\end{array}$ & $\begin{array}{c}\text { Warna } \\
(\mathbf{a}+)\end{array}$ & $\begin{array}{c}\text { Tekstur } \\
(\mathbf{N})\end{array}$ & $\begin{array}{c}\text { Disera } \\
\text { bility }\end{array}$ \\
\hline Prediksi & 2.37 & \multirow{2}{*}{2.07} & 13.89 & 6.00475 & 34.6553 & 17.24 & 1.00 \\
Verifikasi & & & & 5.8 & 34.2 & 17.06 & \\
Residual (\%) & & & 0.20 & 0.45 & 0.18 & \\
Error (\%) & & & 3.53 & 1.33 & 0.01 & \\
\hline
\end{tabular}


Berdasarkan Tabel 8 solusi yang didapatkan dari sistem perhitungan Design Expert, titik optimal variabel konsentrasi kitosan, lama perendaman dan lama penyimpanan adalah 2.22\%, 10 menit dan 13.65 hari penyimpanan pada suhu ruang. Berdasarkan solusi titik optimum variabel bebas diperoleh nilai respon optimum susut buah sebesar $6.0 \mathrm{~g}$, warna a+ 34.65 dan tekstur $17.24 \mathrm{~N}$. Setelah diperoleh hasil solusi kemudian dilakukan validasi model dengan melakukan percobaan sesuai dengan solusi yang disarankan Design Expert. Percobaan menggunakan solusi model tersebut dilakukan pengulangan 3 kali untuk mencegah adanya data tidak sesuai. Validasi hasil optimal dilaksanakan sebagai pembuktian solusi titik optimal variabel bebas yang diperoleh dari program Desain Expert benar-benar menghasilkan hasil respon sesuai dengan respon optimal yang telah ditentukan oleh program dan benar optimal. Menurut Nurmiah et al. (2013), menjelaskan nilai desirability mendekati 1 menunjukkan fungsi optimal yang baik, dimana program program dapat memenuhi tujuan berdasarkan kriteria yang diinginkan pada produk akhir. Nilai desirability ditunjukkan pada Gambar 4.

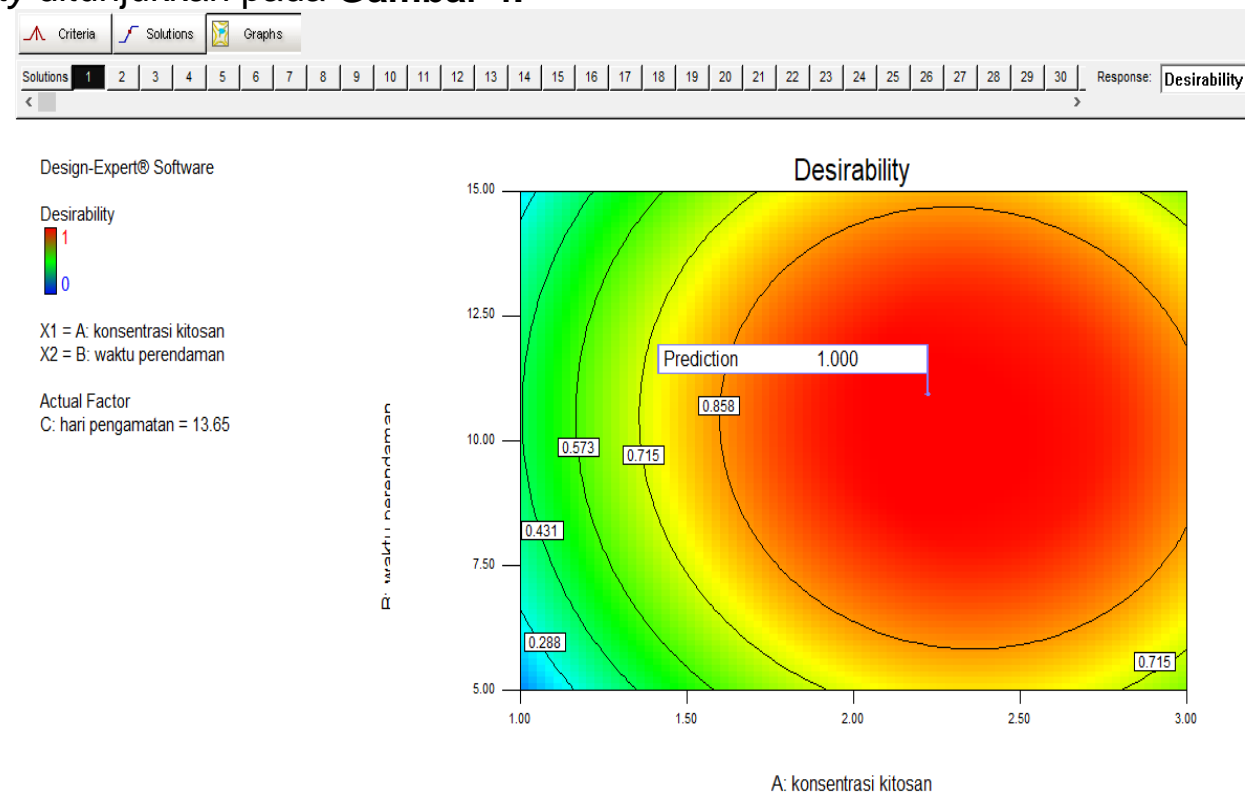

Gambar 4. Grafik Desirability Respon Permukaan

\section{SIMPULAN}

Formulasi optimasi perlakuan terbaik yaitu kosentrasi kitosan $2.22 \%$, lama perendaman 10.52 menit dan lama penyimpanan 13.65 hari menghasilkan susut bobot $5.80 \%$, warna a+ 34.20 dan tekstur $17.06 \mathrm{~N}$.

\section{UCAPAN TERIMA KASIH}

Penulis mengucapakan terima kasih kepada Jurusan Teknologi Hasil Pertanian, Universitas Brawijaya yang telah memberi dukungan terhadap penelitian ini. Penulis juga ingin menyampaikan terima kasih kepada:

1. Kedua orang tua tercinta Bapak Alexander Syakir dan Ibu Rosvina Sedah yang selalu memberikan dukungan baik moril maupun materil, serta doa yang selalu dipanjatkan demi kelancaran penulis.

2. Istri tercinta yang selalu memberikan dukungan serta doanya.

3. Bapak Dr. Ir. Joni Kusnadi, M.Si selaku dosen pembimbing pertama tesis dan sekaligus pemberi dana pada penelitian ini.

4. Ibu Erni Sofia Murtini, STP., MP., PH.D selaku dosen pembimbing kedua tesis yang selalu membantu dan memberikan arahan yang sangat berarti bagi penulis jurnal ini. 
5. Dan kepada semua pihak yang telah membantu, sehingga jurnal ini dapat diselesaikan.

\section{DAFTAR PUSTAKA}

Ardasania I.. (2014). Pengaruh penambahan pektin dan gliserol pada gel lidah buaya (aloe vera) serta lama pencelupan dalam edible coating terhadap kualitas cabai merah besar (capsicum annum, L). Undergraduate Thesis, Universitas Islam Negeri Maulana Malik Ibrahim Malang

Badawy, M. E. I., \& Rabea, E. I. (2009). Potential of the biopolymer chitosan with different molecular weights to control postharvest gray mold of tomato fruit. Postharvest Biology and Technology, 5(1), 110-117.

Cahyono. (2008). Budidaya dan Analisis Usahatani. Yogyakarta: Kanisius

Chen, H., Chih-Hoa, \& Kang, Y. .(2009). Maturation Effect in Fish and HPMC Composite Gel. Food Hydrocolloids, 23, 1756-1761.

Chien, P.-J., F., S., \& Yang, H. . (2007). Effects of edible chitosan coating on quality and shelf life of sliced mango fruit. Journal of Food Engineering, 225-229.

Chien, P. J., Sheu, F., \& Lin, H. R. (2007). Coating Citrus (Murcott Tangor) Fruit With Low Molecular Weight Chitosan Increases Postharvest Quality And Shelf Life. Food Chemistry, 100, 1160-1164.

Fard.K, G., Kamari, S., Ghasemnezhad, M., \& F, G. R. (2010). Effect of Chitosan Coating on Weight Loss and Postharvest Quality of Green Pepper (Capsicum annum L.) Fruits. Acta Hortic 877, 821-826

Ghaouth, Arul, \& Asselin. (1892). Potential Use of Chitosan in Postharvest Preservation of Fruit and Vegetable. Advances in Chitin and Chitosan, 440-452.

Jianglian D. \& Shaoying Z. (2013). Application of Chitosan Based Coating in Fruit and Vegetable Preservation. A Review. J Food Process Technol, 4, 227.

Jiang, \& Tsang, G.. (2005). Lycopene in Tomatoes and Prostate Cancer. Article. Retrieved from: HealthCastle.com

Kays, S (1991). Postharvest Physiology of Perishable Plant Product. New York: AVI Book

Melly, N., Satriana, Martunis, Rohaya, S., \& Hasmarita, E. (2012). Pengaruh Pelapisan Kitosan Terhadap Sifat Fisik Dan Kimia Tomat Segar (Lycopersicum pyriforme) Pada Berbagai Tingkat Kematangan. Jurnal Teknologi Dan Industri Pertanian Indonesia, 4(3).

Montgomery, D. (2001). Design dan Analysis of Experimental. Jonh Wiley and Sons Inc.

Nurmiah, S, Syarief R, Sukarno, Peranginangin R, Nurmata B (2013). Aplikasi Response Surface Methodology Pada Optimalisasi Kondisi Proses Pengolahan Alkali Treated Cottonii ( ATC ). JBP Kelautan dan Perikanan 8 (1) 9-22

Prabha, R.A, \& Sivakumar K. (2015). Application of Chitosan in Food Preservation. International Journal of Science and Research, 6 (7).

Raymond, L. V., Zhang, M., \& Roknul Azam. (2012). Effect of Chitosan Coating on Physical and Microbial Characteristics of Fresh-Cut Green Peppers (Capsicum annuum L.). Journal of Nutrition, 11(10).

Saputro M. A. P, \& Susanto W. H.. (2016). Pembuatan Bubuk Cabai Rawit (Kajian Konsentrasi Kalsium Propionat Dan Lama Waktu Perebusan Terhadap Kualitas Produk. Jurnal Pangan Dan Agroindustri, 4(1), 62-71.

Sitorus, R. F., Karo-Karo, T., \& Lubis, Z. (2014). Pengaruh Konsentrasi Kitosan Sebagai Edible Coating Dan Lama Penyimpanan Terhadap Mutu Buah Jambu Biji Merah. J.Rekayasa Pangan Dan Pert, 2(1).

Susanto, T. (2006). Fisiologi Teknologi Pasca Panen. Yogyakarta. Akademia

Susilowati. (2008). Isolasi dan identifikasi senyawa karotenoid dari cabai merah (capcicum annum Linn). Undergraduate Thesis, Universitas Islam Negeri Maulana Malik Ibrahim Malang

Syahri, \& Renny Utami Somantri, T. (2018). Penanganan Segar Untuk Mempertahankan Mutu Dan Menekan Susut Bobot Cabai Selama Penyimpanan. Balai Pengkajian 
Optimasi Penambahan Kitosan dan Lama Perendaman - Perkasa, dkk Jurnal Pangan dan Agroindustri Vol. 9 No.1: 13-24, Jan 2021

Teknologi Pertanian (BPTP) Sumatera Selatan.

Trotel-Aziz, P., Couderchet, M., \& Ardasania. 2014. Pengaruh penambahan pektin dan gliserol pada gel lidah buaya (aloe vera) serta lama pencelupan dalam edible coating terhadap kualitas cabai merah (capsicum annum, L).

Yage, X., Xihong, L., Xu, Q., Yun, J., Lu, Y., \& Y, T. (2010). Effects of Chitosan Coating Enriched with Cinnamon Oil on Qualitative Properties of Sweet Pepper (Capsicum annuum L.). Food Chemistry, 124, 1443-1450. 